\title{
Penelitian Awal Kualitas Papan Partikel Plastik yang Terbuat dari Limbah Tandan Kosong Kelapa Sawit dan Ampas Tebu
}

\section{A Preliminary Study on Quality of Plastic Particle Board Made From Empty Palm Fruit Bunch and Sugarcane Bagasse}

\author{
Muhammad Yamin*1, Elisa Ginsel Popang ${ }^{1}$, Mujibu Rahman ${ }^{1}$, Rudito $^{1}$, Jamaluddin $^{2}$, \\ Sarbin $^{3}$ \\ ${ }^{1}$ Program Studi Teknologi Hasil Perkebunan, Politeknik Pertanian Negeri Samarinda, Indonesia. \\ ${ }^{2}$ Program Studi Budidaya Tanaman Perkebunan, Politeknik Pertanian Negeri Samarinda, Indonesia. \\ ${ }^{3}$ Program Studi Pengolahan Hasil Hutan, Politeknik Pertanian Negeri Samarinda, Indonesia. \\ ${ }^{*}$ Correspondence Author: yaminpolitani@gmail.com
}

\begin{abstract}
ABSTRAK
Limbah Plastik, tandan kosong kelapa sawit dan ampas tebu merupakan polusi padat yang selain lambat terdegredasi juga merupakan polusi bagi lingkungan. Penelitian ini bertujuan untuk membuat dan menguji papan partikel plastik berkerapatan rendah guna peruntukan dalam bidang bangunan. Rancangan exprimen menggunakan uji kualitas papan partikel terbaru yakni SNI 03-2105-2006 dan FAO 1996 dengan perbandingan 50\% limbah tebu dan $50 \%$ limbah plastik, begitupun untuk percobaan lainnya yakni $50 \%$ tandan kosong sawit dan $50 \%$ limbah plastik, dengan 3 kali ulangan untuk setiap percobaan. Hasil studi menunjukkan bahwa kualitas papan partikel berkerapatan rendah dari limbah tebu yang sesuai standard SNI 03-2105-2006 kerapatan, kadar air, pengembangan tebal dan MOR serta tarik tegak lurus permukaan, sedangkan dari limbah tandan kosong sawit yang sesuai dengan SNI adalah kerapatan, kadar air dan MOR. Adapun nilai MOE kedua percobaan tidak sesuai dengan SNI, namun untuk standar FAO 1996, kedua ujicoba menunjukkan MOE terdapat kesesuaian dengan nilai standar. Studi penelitian dasar ini menunjukkan bahwa kualitas papan partikel menggunakan limbah tebu lebih baik daripada papan partikel yang menggunakan tandan kosong sawit untuk material bangunan berdasarkan nilai MOE dan MOR.
\end{abstract}

Kata Kunci: Tandan Kosong Kelapa Sawit, Ampas Tebu, Papan Partikel

\section{ABSTRACT}

Plastic waste, empty palm fruit bunch (EPFB) and sugarcane bagasse (SB) are the slowly degradable pollutants that can reduce fertility of the soil and damage the environment. The objective of this study was to compare the quality of low density plastic particle board made from empty palm fruit bunch and sugarcane bagasse based on the standard of SNI 032105-2006 and FAO 1996. Experimental design was used by testing the quality of particle boards with substitution $50 \%$ by weight of total mixes for each waste (EPFB and SB) and $50 \%$ of plastic waste with 3 replications. The results revealed that the quality of the low density particle boards based on water content, density, and modulus of rupture (MOR) meet the requirements of SNI 03-2105-2006, whereas the modulus of elasticity (MOE), thickness swelling, water absorption, and the tension perpendicular to surface tests do not comply the requirements except tension perpendicular tests for sugarcane bagasse. Furthermore, based on MOE and MOR value, this study revealed that the quality of particle boards made from empty palm fruit bunch (EPFB) was better than the particle boards made from sugarcane bagasse (SB) for building materials.

Keywords: Empty Palm Fruit Bunch, Sugarcane Bagasse, Particle Board 


\section{PENDAHULUAN}

Ada banyak limbah pertanian yang saat ini terbuang dan tidak mengalami recycling, dikarenakan selain sulitnya diolah juga lambatnya terdegredasi di alam. Limbah tebu merupakan limbah yang terus bertambah setiap harinya dan menjadi masalah dalam hal pencemaran lingkungan., karena lambarnya proses degredasi alam.

Problem lingkungan yang sama juga muncul dari limbah tandan kosong sawit yang dihasilkan dari pabrik prngolahan sawit menjadi CPO. Tahun 1993 luas tanaman kelapa sawit diperkirakan 14,7 juta ha, yang mana untuk Kalimantan Timur saja potensi limbah berupa tandan kosong sawit dari hasil pengolahan adalah sekitar 1.096.646 ton/ha (Fauzi et al.,2004). Limbah bahaya lain yang tak bisa disepelekan adalah limbah plastik . limbah plastik bisa mencegah produksi nutrisi dalam tanah, sehingga tingkat kesuburan tanah bisa berkurang dan akibatnya berpengaruh terhadap produksi pertanian dan perkebunan (Gopal et al, 2014).

Salah satu usaha untuk mengurangi limbah lingkungan ini adalah melakukan proses recycle.Limbah tersebut menjadi papan partikel. Penelitian papan partikel telah banyak dilakukan oleh beberapa peneliti. Papan partikel terdiri atas tiga jenis kerapatan , yakni kerapatan rendah (< $\left.0,59 \mathrm{~g} / \mathrm{cm}^{3}\right)$, kerapatan sedang $(0,59-$ $0,8) \mathrm{g} / \mathrm{cm}^{3}$, dan kerapatan tinggi ( $>0,8$ $\mathrm{g} / \mathrm{cm}^{3}$ ). Penelitian ini diarahkan untuk menghasilkan papan yang berkualitas dengan jenis kerapatan rendah, agar dalam pembuatan papan partikel plastik dari limbah plastik dan perkebunan ini bisa meminimalkan biaya produksi. .

Ini tentunya sangat sesuai dalam penghematan material dan menghasilkan produk yang lebih banyak karena tidak menggunakan kerapatan tinggi dalam pembuatan produk, kualitas produk yang lebih baik dan ongkos produksi lebih kecil menjadi harapan dalam penelitian ini.

\section{BAHAN DAN METODE}

Penelitian ini bertujuan untuk membandingkan kualitas papan partikel plastik yang dihasilkan dari limbah tebu dan limbah tandan kosong sawit (tangkos) dengan penggunaan limbah plastik sebagai perekat (polypropylene). Penelitian dilakukan dengan dua perlakuan dan tiga kali ulangan. Berat kering dari masingmasing bahan papan adalah $162 \mathrm{~g}$. Rancangan percampuran adalah sebagai berikut $50 \%$ limbah tebu : 50\% limbah plastik dan juga $50 \%$ limbah tangkos : $50 \%$ of limbah plastik (dari berat total percampuran).

Pengepresan panas dilakukan dalam press hidraulic, padat $175^{\circ} \mathrm{C}$ temperature dan tekanan $30 \mathrm{~kg} / \mathrm{cm}^{2}$ tekanan panas dilakukan sekitar 7 menit. Semua produk papan partikel yang telah jadi dikondisikan dalam sebuah ruang selama empat hari sebelum dilakukan pengujian.

Uji fisik dan mekanik dilaksanakan di laboratorium teknologi produksi hutan di Universitas Mulawarman. Uji meliputi beberapa parameter seperti kandungan air. Penyerapan air, pengembangan tebal, kerapatan, Keteguhan lentur (MOE), dan keteguhan patah (MOR) berdasarkan SNI 03-2105-2006 dan tarik sejajar permukaan berdasarkan standar FAO 1996 standard (FAO,1997), Setelah pendinginan, pemotongan papan partikel dilakukan untuk pengetesan fisik dan mekanik . pada gambar 1 adalah contoh ,pemotongan sampel untuk diuji sesuai peruntukannya..

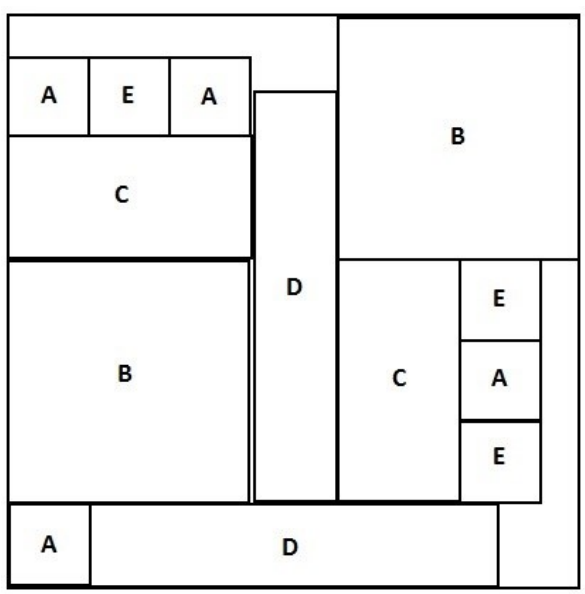

Gambar 1. Pola Pemotongan Produk untuk Uji fisik dan Mekanik.

Dimana $A$ adalah untuk pengujian untuk uji kandungan air dan kerapatan $(5 \mathrm{~cm} \times 5$ 
$\mathrm{cm})$, B adalah untuk penyerapan air dan pengembangan tebal $(15 \mathrm{~cm} \times 15 \mathrm{~cm}), C$ untuk pengukuran MOE and MOR (15,2 $\mathrm{cm} \times 7,6 \mathrm{~cm})$, $D$ untuk tarik tegangan sejajar permukaan $(25,4 \mathrm{~cm} \times 5,1 \mathrm{~cm})$, dan $\mathrm{E}$ adalah untuk tarik tekan tegak lurus permukaan $(5 \mathrm{~cm} \times 5 \mathrm{~cm})$ dengan ketebalan produk sampel adalah $0,6 \mathrm{~cm}$.

\section{HASIL DAN PEMBAHASAN}

\subsection{Kadar Air}

Rata-rata nilai kandungsan air papan partikel plastik yang terbuat dari limbah tebu (LT) dan Limbah tandan kosong sawit (LTKS ) adalah sebagai berikut 1,67\% and $2,44 \%$. Pada gambar 2 menunjukkan bahwa hasil masih sesuai dengan standar (SNI,2006) yang mana maksimum nilainya adalah $14 \%$. Rendahnya nilai kadar air ini disebabkan oleh proses pengeringan limbah material yang dilakukan sebelum pengepresan panas.

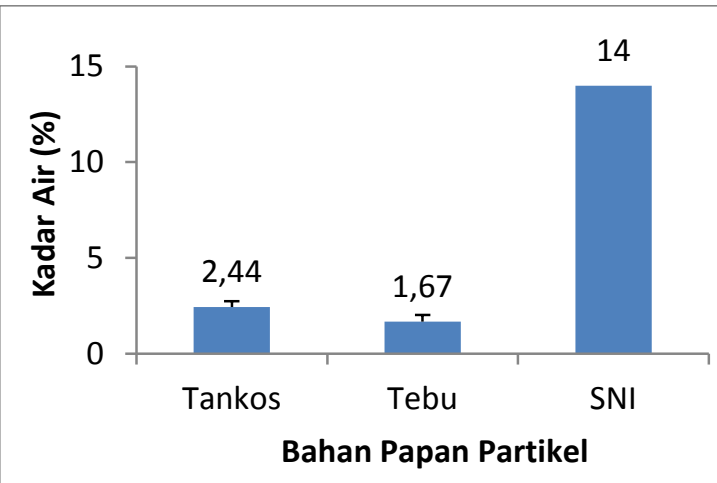

Gambar 2 . Perbandingan Kadar Air Papan Partikel dari Limbah Tandan Kosong Sawit dan Limbah Tebu dengan Menggunakan Adhesive Plastik

\subsection{Penyerapan Air}

Uji Penyerapan air adalah batas kemampuan jumlah air yang diserap oleh papan partikel plastik sehingga terjadi peningkatan tebal dari papan partikel. Sesuai dengan gambar 3, penyerapan air berdasarkan standar FAO (FAO,1996) adalah (6\%-40\%), dilakukan penilaian dengan standar FAO karena pada standar SNI 1996, nilai penyerapan air ini tidak masuk dalam standar hitungan papan partikel. Adapun hasil percobaan menunjukkan rata-rata nilai penyerapan air adalah $82,38 \%$ untuk papan partikel plastik dari limbah Tandan kosong Sawit dan $44,07 \%$ untuk limbah tebu.

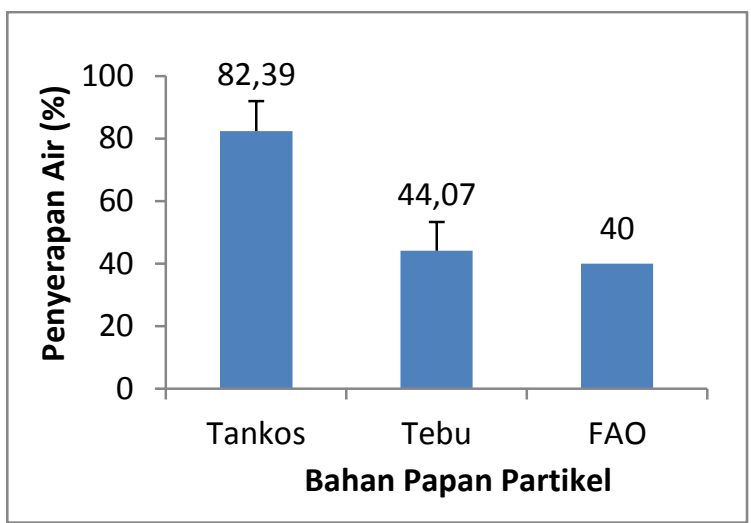

Gambar 3. Perbandingan penyerapan air Papan Partikel dari Limbah Tandan Kosong Sawit dan Limbah Tebu dengan Menggunakan Adhesive Plastik

\subsection{Pengembangan Tebal}

Pengembangan tebal bertujuan untuk mengetahui perubahan ketebalan akibat rembesan air yang masuk di pori-pori papan pada periode waktu tertentu. Menurut standar SNI Papan Partikel 2006 nilai maksimum pengembangan tebal adalah $20 \%$, Gambar 4 menunjukkan bahwa pengembangan tebal papan plastik dari bahan tebu adalah sebesar 5,09\%. Nilai pengembangan tebal ini telah memenuhi kriteria dalam standar yang diharapkan yaitu maksimun $12 \%$. Adapun papan plastik dari limbah tandan kosong sawit tidak memenuhi kriteria standar karena memiliki nilai uji pengembangan tebal sebesar $20,70 \%$.

Distribusi rembesan air yang menyebabkan pengembangan tebal berbeda pada setiap percobaan namun dari rata -rata nampak bahwa limbah Tandan kosong sawit memilki nilai lebih besar daripada papan plastik dari limbah tebu. Hal ini bisa jadi porositas dari limbah tangkos lebih besar dari pada limbah tebu sehinga lebih banyak menyerap air. Demikian juga kuatnya penyatuan serat tebu, menyebabkan porositas semakin sedikit. Hal inilah yang menyebabkan nilai pengembangan tebal papan plastik dari limbah tebu dapat memenuhi standar yang ditetapkan yakni kurang dari $20 \%$. 


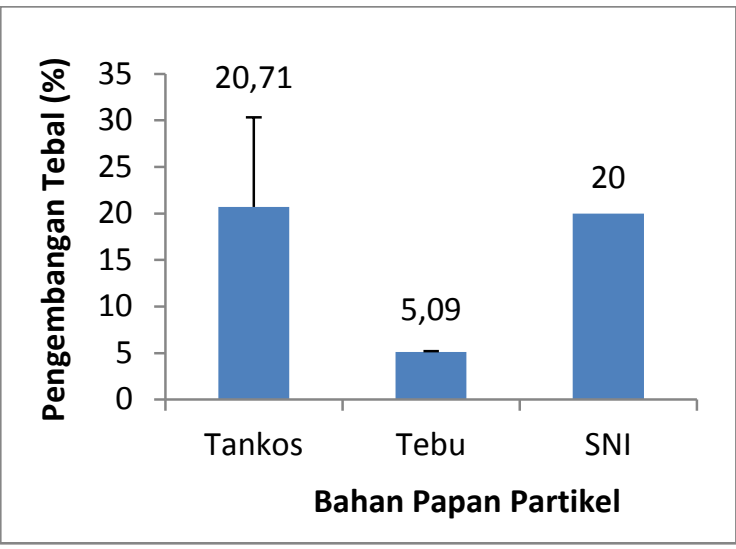

Gambar 4. Perbandingan pengembangan tebal Papan Partikel dari Limbah Tandan Kosong Sawit dan Limbah Tebu dengan Menggunakan Adhesive Plastik.

\subsection{Kerapatan}

Kerapatan dipengaruhi oleh jumlah massa partikel baik dari limbah tankos ataupun limbah tebu sebagai bahan penyusun dari papan partikel plastik. Semakin banyak massa partikel maka semakin besar nilai kerapatan pada papan partikel tersebut. Berdasarkan standar kerapatan yang ada yakni dengan nilai diantara $(0,40-0,90) \mathrm{g} / \mathrm{cm}^{3}$ dan standar FAO 1996 yakni $(0,42-0,80) \mathrm{g} / \mathrm{cm}^{3}$. Gambar 5 menunjukkan bahwa nilai kedua sampel produk baik yang berasal dari limbah tangkos ataupun limbah tebu masing-masing memenuhi yakni untuk limbah tangkos adalah $0,54 \mathrm{~g} / \mathrm{cm}^{3}$ sedangkan untuk limbah tebu adalah 0,56 $\mathrm{g} / \mathrm{cm}^{3}$.

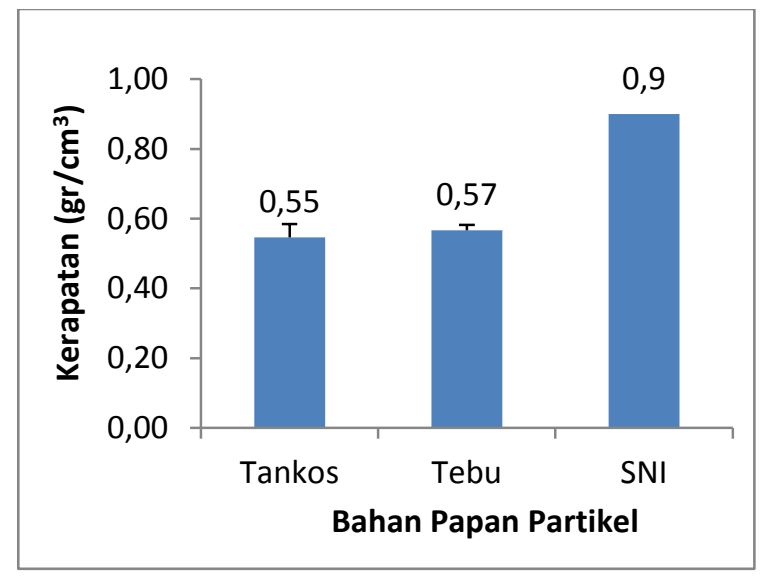

Gambar 5. Perbandingan kerapatan Papan Partikel dari Limbah Tandan Kosong Sawit dan Limbah Tebu dengan Menggunakan Adhesive Plastik.

\subsection{Tegangan Lentur I Modulus of Elasticity (MOE)}

Test Tegangan Lentur atau Modulus of elasticity (MOE) adalah semacam studi kemampuan papan partikel menerima beban maksimum dan kembali kebentuk semula jika beban dihilangkan.

Nilai minimum MOE berdasarkan SNI 03-2105-2006 adalah $20.400 \mathrm{~kg} / \mathrm{cm}^{2}$. Dari gambar 6 , hasil rata-rata menunjukkan bahwa nilai keduanya (Tandan Kosong Sawit memiliki nilai $2778 \mathrm{~kg} / \mathrm{cm}^{2}$ sedangkan limbah tebu adalah 9042 $\mathrm{kg} / \mathrm{cm}^{2}$ ) kedua nilai tidak memenuhi persyaratan dari standar yang ada).

Ini merupakan hasil yang tidak demikian bagus jika dibandingkan dengan bahan perekat menggunaka urea formaldehyde atau phenol formaldehyde.

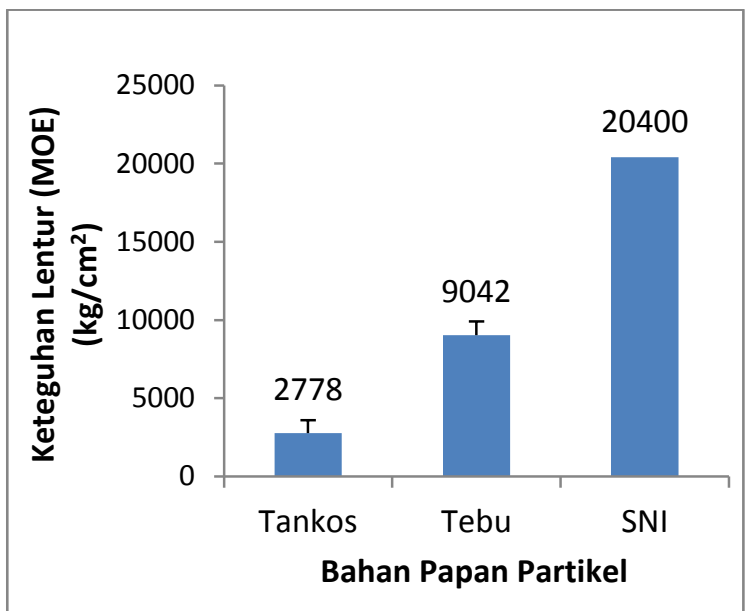

Gambar 6. Perbandingan MOE Papan Partikel dari Limbah Tandan Kosong Sawit dan Limbah Tebu dengan Menggunakan Adhesive Plastik.

\subsection{Tegangan patah I Modulus of Rupture (MOR)}

Pengujian Tegangan Patah (MOR) adalah menggunakan metode yang sama pada pengukuran tegangan elastis (MOE), Papan partikel akan diberi beban semaksimal mungkin sampai pada batas dimana perubahan bentuk papan patrikel tidak bisa lagi balik ke bentuk semula. Dan jika ditambah bebean akan menyebabkan papan partikel plastik patah. Nilai tegangan patah ini sangat penting dalam menetapkan kualitas sebuah papan partikel plastik sebagai material bangunan. 
Nilai minimum dari MOR berdasarkan SNI 03-2105-2006 adalah $82 \mathrm{~kg} / \mathrm{cm}^{2}$. Pada nilai yang ditunjukkan di gambar 7 , bahwa kedua sampel yang ditetapkan memenuhi dengan rata-rata $186 \mathrm{~kg} / \mathrm{cm}^{2}$ untuk limbah tebu dan $157 \mathrm{~kg} / \mathrm{cm}^{2}$ untuk limbah tangkos.

Nilai MOR yang memenuhi standar bisa disebabkan oleh pada padatnya plastik sebagai adhesive dan homogennya distribusi percampuran antara limbah plastik dan limbah partikel selama proses percampuran berlangsung. Karea kuatnya daya patah disebabkan juga proses adhesive yang ada pada bahan.

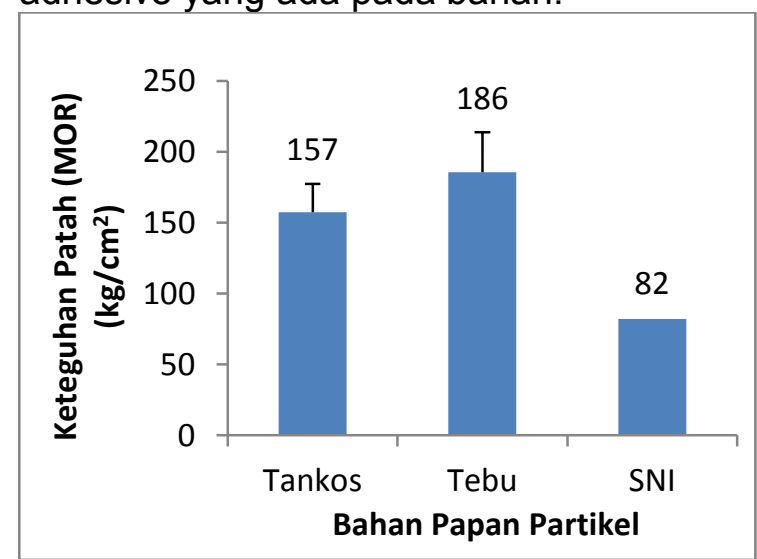

Gambar 7. Perbandingan MOR Papan Partikel dari Limbah Tandan Kosong Sawit dan Limbah Tebu dengan Menggunakan Adhesive Plastik.

\subsection{Keteguhan Tarik Tegak Lurus Permukaan}

Nilai dari Keteguhan Tarik Tegak Lurus Permukaan dari sampel uji papan partikel plastik, menurut standar dalam standar SNI 2006 yakni minimum $1,5 \mathrm{kgf} / \mathrm{cm}^{2}$, gambar 8 menunjukkan bahwa nilai memenuhi standar yang ada yakni adalah limbah tebu yang memilki nilai $2,65 \mathrm{kgf} / \mathrm{cm}^{2}$ sedangkan limbah tangkos adalah $0,78 \mathrm{kgf} / \mathrm{cm}^{2}$ belum memenuhi standar yang ditetapkan, hal ini ada kemungkinan disebabkan meratanya adhesive pada limbah tebu karena kehomogenan serat pada limbah tebu, sehingga daya ikat yang tinggi menyebabkan nilai tarik tegak lurus permukaan lebih baik

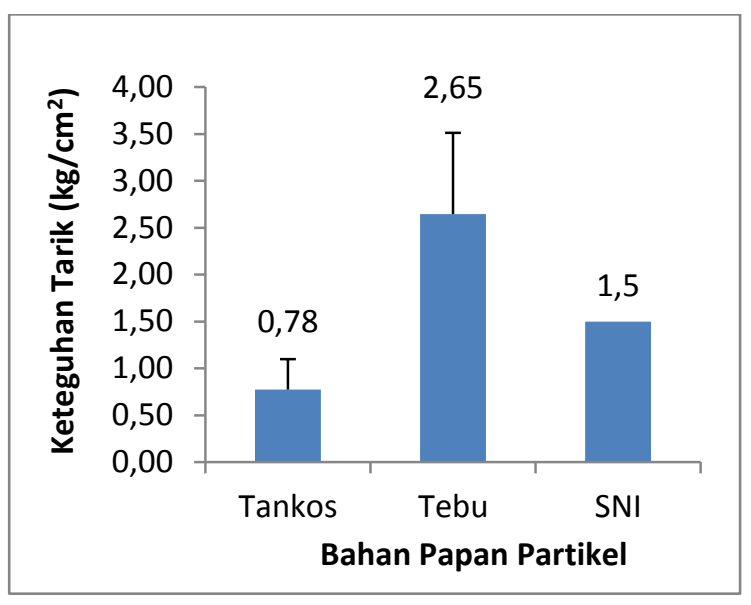

Gambar 8. Perbandingan Keteguhan Tarik Tegak Lurus Permukaan Papan Partikel dari Limbah Tandan Kosong Sawit dan Limbah Tebu dengan Menggunakan Adhesive Plastik.

\section{KESIMPULAN}

Penelitian papan partikel plastik dengan berkepadatan rendah ini mennujukkan beberapa hasil yakni kadar air, kepadatan dan tegangan Patah (MOR) sesuai dengan persyaratan standar SNI 03-2105-2006 dan standar FAO 1996, sedangkan untuk nilai tegangan elastis (MOE), pengembangan tebal, daya serap air serta nilai Keteguhan Tarik Tegak Lurus Permukaan belum memenuhi standar yang ditetapkan, kecuali untuk tarik tegak lurus permukaan pada limbah tebu.

Pada penelitian pendahuluan ini menunjukkan kualitas dari penggunanan limbah sawit sebagai papan partikel plastik lebih baik dari pada jika menggunakan limbah tebu, khususnya sebagai material bangunan disebabkan nilai MOR yang lebih baik.

Pada penelitian pendahuluan ini, bagaimanapun analisis selanjutnya diperlukan untuk menemukan dosis variasi yang tepat dan sesuai sehingga ditemukan produk yang paling ideal untuk dikembangkan, atau tidak menutup kemungkinan antara partikel limbah tersebut dilakukan mixturisasi dengan limbah-limbah perkebunan lainnya seperti limbah sekam, yang mana terutama untuk mengelola limbah perkebunan yang lebih baik dan lebih bermanfaat. 


\section{DAFTAR PUSTAKA}

Fauzi, Y. E. Widiastuti, I. Stayawibawa, R. Hartono. 2004. Kelapa sawit: Budidaya pemanfaatan hasil dan limbah, analisis usaha dan pemasaran. Penebar Swadaya. Jakarta.

Gopal, N,M.D., Phebe, P., Kumar, EV.S., Vani, B.K.K. 2014. Impact of plastik leading environmental pollution. Journal of Chemical and Pharmaceutical Sciences. Special issue 3; pp. 96-99. 2

Maloney, T.M. 1993. Modern particleboard and dry process fiberboard manufacturing. San Fransisco, Miller Freeman Inc.

Badan Standardisasi Nasional. 2006. SNI 03-2105-2006. Papan Partikel.

FAO. 1996. Fiberboard and particle Board. (1996). Genewa. 